\title{
WHAT TEACHERS NEED; CARRYING OUT ISLAMIC BASED DIGITAL LITERACY ASSESSMENT THROUGH THE PROJECT
}

\author{
Nazriani Lubis ${ }^{1)}$, Alkausar Saragih $^{2}$, Asnarni Lubis ${ }^{3)}$ \\ Universitas Muslim Nusantara Al Washliyah ${ }^{1)}$ \\ Universitas Muslim Nusantara Al Washliyah ${ }^{2)}$ \\ Universitas Muslim Nusantara Al Washliyah ${ }^{3)}$ \\ nazrianilubis@umnaw.ac.id
}

\begin{abstract}
The community service program focuses on improving senior high school teachers' ability in carrying out Islamic-based digital literacy assessment through Project-based Learning. It is empirically revealed by the research that Project-based Learning with video project serves considerable benefits, specifically, it leads to Islamic-based digital literacy assessment. The reality shows that teachers of MTS.Swasta Lab IKIP Al Washliyah located in Medan Amplas have never experienced digital literacy assessment journey since they tend to apply silent reading, and memorizing. Through this program, the teachers are comprehensively trained to implement, to design, to innovate the video project linking to Islamic values in which all values experienced by students are assessed based on digital literacy skill with available online application. Therefore, the assessment of Islamic-based digital literacy is carried out to gather the information of students' process (reading, writing, and applying online digital tools) rather than scoring or numbers. Based on analysis, it is found that most teachers strongly agree with program that can be seen from six indicator achieved. It implies that it becomes challenging, yet authentic in involving teacher to have digital journey, particularly, in new normal era.
\end{abstract}

Keywords; digital literacy, Islamic-based assessment, high school teachers, project-based learning

\begin{abstract}
ABSTRAK
Program pengabdian masyarakat difokuskan pada peningkatan kemampuan guru dalam melaksanakan penilaian literasi digital berbasis Islam melalui Project-based Learning. Secara empiris terungkap dari hasil penelitian bahwa Project-based Learning dengan proyek video memberikan manfaat yang cukup besar, khususnya mengarah pada penilaian literasi digital berbasis Islam. Kenyataan menunjukkan bahwa guru MTS.Swasta Lab IKIP Al Washliyah yang berlokasi di Medan Amplas tidak pernah melakukan asesmen literasi digital karena cenderung menerapkan silent reading, dan hapalan. Melalui program ini, para guru dilatih secara komprehensif untuk mengimplementasikan, merancang, menginovasi proyek video yang dihubungkan dengan nilai-nilai Islam di mana semua nilai keislaman yang dialami siswa dinilai berdasarkan keterampilan literasi digital dengan aplikasi online yang tersedia. Oleh karena itu, penilaian literasi digital berbasis Islam dilakukan untuk mengumpulkan informasi siswa selama proses menyelesaikan proyek (membaca, menulis, dan mengaplikasikan perangkat digital online) daripada melakukan penilaian dengan angka. Berdasarkan hasil analisis diketahui bahwa sebagian besar guru sangat setuju dengan adanya program yang dapat dilihat dari enam indikator yang dicapai. Ini menyiratkan bahwa menjadi tantangan, namun otentik dalam melibatkan guru dalam perjalanan digital, khususnya di era new normal.
\end{abstract}

Kata Kunci; Guru Sekolah Menengah, Literasi Digital, Project-based Learning, Penilaian berbasis Islam 


\section{INTRODUCTION}

\subsection{Background of Study}

The development of technology offers a new nuance of teaching since it can be integrated with teaching strategy, model, and assessment that are appropriate to today's students need, namely; digital literacy skill. Recently, the disruption era leads to digital literacy skill in which the students are expected to be able to understand, to analyze, and to create both written and spoken languages creatively through digital media. Certainly, this current situation makes the teachers are also brought up to create the enjoyable and meaningful learning process by using digital technology.

Yet, most senior high school teachers of Mts.Swasta Lab IKIP Al Washliyah still have obstacles, and difficulties to be friendly with the digital technology. In details, the result of observation conducted in Mts.Swasta Lab IKIP Al Washliyah located in Medan city shows that the teachers tend to implement conventional teaching method in improving students' literacy skill through some regular reading activities, such as; answering the question given, memorizing the materials, and reciting Asmaul
Husnah, Al Qur'an or Hadits, Then, the students will be assessed by teachers based on their ability to memorize. Whereas, students' literacy skill must be shifting to digital literacy skill, so that the teachers have to become more skillful in assessing students' digital literacy acquisition.

In details, there four major problems faced by teahers of MTs.Swasta Lab IKIP Al Washliyah, namely; they have never implemented Project-based Learning, they have never run digital literacy assessment, they have never experienced to combine Islamic values with project, they have focused on silent reading, memorizing for acquiring literacy skill.

To overcome these problems, this community program offers the solution that is created based on the research result. A study reports that the implementation of Projectbased Learning significantly affects on students' creativity in creating the project, and students' communication skill in presenting what they have done through digital media (Lubis, 2018). It is believed that the students' ability of creating the project, and expressing the idea is connected to digital literacy skill since the students have the opportunities to read, to write, and to speak on online digital platform.

Moreover, another research also reveals that students need to be guided for owning digital learning journey that is constantly increased by using of online learning sources (Greaves, Bradley, Holley, 2012). Whilst, the students in Iran have low 
to moderate digital literacy skill, yet teachers believe that students' digital literacy skill can reach any purposes needed by high school students (Dashtestani, Hojatpanah, 2020).

Indeed, due to the characteristic of Islamic owned by the school Mts.Swasta Lab IKIP Al Washliyah, this community service program tends to focus on improving teachers' ability of Islamic-based digital literacy skill assessment through implementation of Project-based Learning

\subsection{The Objectives of Community Service}

Based on the background of study, the objectives of community service program are stated as follows;

1. To investigate the improvement of teaches' ability in running the assessment of Islamicbased digital literacy skill

2. To improve teachers' capability to implement Project-based learning.

3. To enhance teachers' creativity in creating the project connected with Islamic values.

4. To increase teachers' awareness of using digital tools to improve students' digital literacy skills.

\subsection{Method of Problem-Solving Approach}

In order to achieve the objectives of the program, the method of problem-solving approach used is training of implementation of Project-based
Learning that is integrated with digital assessment. It is empirically proved that Project-based Learning leads to the multi purposes, which teacher can direct the students to involve in digital literacy activities during project completion (Lubis, 2018). Moreover, teacher can easily to assess the project that is linked to Islamic values. For example, science teachers design the project of photosynthesis process that is linked to Al Qur'an or Hadits. Thus, teacher are expected fulfil the National Education Standard and Indonesia Government Regulation No 19 Year 2005, and No 32 Year 2013 state that one of indicators that have to be achieved is creating interactive, challenging, enjoyable learning process (Mulyasa, 2013) in order to improve students' skill, talent, and creativity so that students are growing with real world skills.

\section{METHOD OF RUNNING THE PROGRAM}

To successfully carry out the program, there are six stages conducted;

1. Preparation

In this stage, the community service team completely prepare a permit to the school, administrative requirements. They also prepare training facilities and infrastructure needed.

2. Socialization

In this stage, the team visit the school and conduct the interview with the principal and teacher representatives to investigate the major problems faced. Then, the team socialized and offer the solution that is the implementation of Projectbased Learning to improve 
teachers' capability of making Islamic-based digital literacy skill assessment.

3. Training of Project-based Learning

At this stage, the service team carry out training activities on the implementation of Projectbased Learning for making Islamic-based digital literacy assessments at MTS.s Lab IKIP Al Washliyah. The service team starts this activity by preparing materials, facilities and infrastructure then it proceeds to the distribution training materials. In this training activity, the service team presented material about the current shift in digital-based assessment, and a demonstration of the implementation of Projectbased Learning, which is related to stages, language use (literacy) and assessment indicators. This activity will end with monitoring and mentoring until teachers are able to implement projectbased learning and digital literacy, and complete Islamic values.

4. Introduction to Digital Literacy Assessment Variations.

At this stage, the service team will demonstrate a variety of digital literacy assessments. The service team together with the teacher conducted video analysis to investigate the use of language, steps, and the level of creativity of the video project by focusing on assessment of learning and assessment for learning with digital application such as; google form, voccaro, and kahoot.
To completely arrive at the final aims of the program, the teachers are kept monitoring through two kinds activities, namely; small group discussion, and evaluation in order to sustain the program.

\section{RESULT DISCUSSION}

AND

\subsection{The Result of Teachers' Awareness on the Importance of Assessment in Leaning Process}

In this case, the initial stage is carried out prior to the training conducted through field survey. The survey team consists of 3 people, each survey team give an assessment to 5 respondents, so that the number of respondents is 15 participants. The analysis is performed by using IBM SPSS 23 for windows, using the following conditions. It describes the output with the provisions of the Barletts sphericity test and Kiser-Mayer-Olkin (KMO) to determine the adequacy of the sample. According to Suliyanto (2005: 2), it is known that there are categories of KMO values, namely:

- 0.9 is very good

- 0.8 is good

- 0.7 is moderate

- 0.6 is sufficient

- 0.5 is insufficient

- less than 0.5 are rejected

To determine the number of factors, representative variables are analyzed based on the magnitude of the eigenvalue and the percentage of total variance, 
then only factors that have an eigenvalue equal to or higher than one maintained in the factor analysis model, then it is analyzed by extracting the factors in the factor matrix. identify the relationship among factors and individual variables, so that the matrix is transformed into a simpler matrix using the varimax procedure. Furthermore, it is followed by interpreting the factors by classifying the variables that have a minimum loading of 0.4 while variables with a factor loading less than 0.4 are excluded from the model. The results obtained from the result of survey is clearly seen in table 1.

\section{Table 1. The Result of Survey}

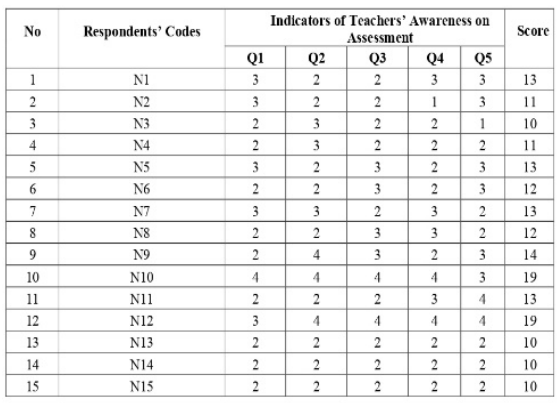

From the table above, it can be seen that there are five question given; Q1 for teacher' ignorance toward the digital assessment, Q2 for teachers' awareness of using technology, Q3 for insufficient information about digital literacy skill assessment, Q4 for creative thinking, and Q5 for digital assessment convenience. Then, all the data found is analyzed by using KMO and Bartlett's Test as seen as Table 2 .
Table 2. The Result of KMO and Bartlett's Test

\begin{tabular}{|ll|r|}
\hline Kaiser-Meyer-Olkin Measure of Sampling & .770 \\
Adequacy. & & 19.457 \\
Bartlett's Test of & Approx. Chi-Square & 10 \\
Sphericity & df & .035 \\
& Sig. & \\
\hline
\end{tabular}

The table above clearly seen that KMO and Barlett's test values for the correlation between the desired variables are higher than $0.5(>0.5)$ and the research significance is 0.35 . From the results above, it is obtained $\mathrm{KMO}$ of 0.770 , in accordance that is in the medium category and is higher than 0.5 , then the acquisition of significant indigo (Barlett's test of Sphericity) is 0.035 . Thus, it can be said that the variables and respondents used allow for further analysis. Furthermore, to see the correlation between independent variables, it can be shown in the Anti-Image Matrics table. The value that is considered in MSA (Measure of Sampling Adequacy). MSA value ranges from 0 to 1 , with the following conditions:

- $\mathrm{MSA}=1$, the variable can be predicted without error by other variables

- MSA>0.5 variable can still be predicted and can be further analyzed

- MSA $<0.5$ variable is unpredictable and cannot be analyzed.

Furthermore, all the data are analyzed by using SPSS as clearly visualized in table 3 . 
Tabe 3. The Result of Data Analysis

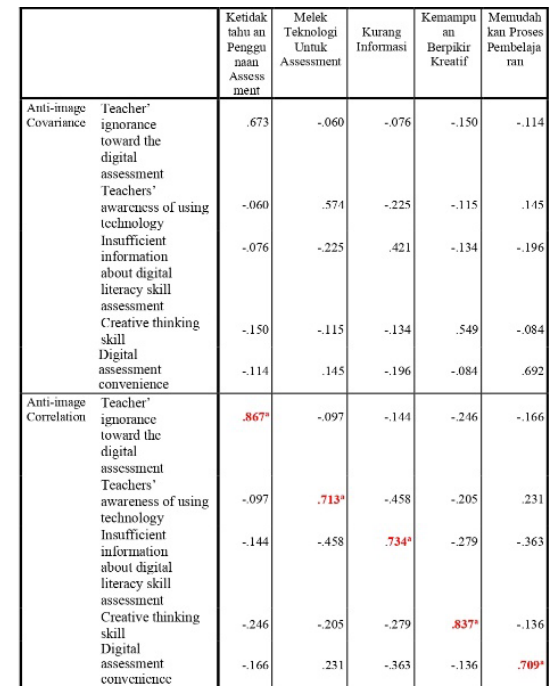

From the table above, it can be explained that the MSA value is marked with the letter a, then the following results are obtained:

- Teacher' ignorance toward the digital assessment: $0.867>0.5$

- Teachers' awareness of using technology: 0.713> 0.5

- Insufficient information about digital literacy assessment: $0.734>0.5$

- Creative thinking: 0.837> 0.5 .

- Digital technology convenience $0,709>0,5$

Based on the results of the MSA above, it is known that all independent variables can be analyzed further because each one is still within the stipulations which are predictable. Then, it is shown in the following table:
Table 4. The Result of Data Analysis

\begin{tabular}{|l|r|r|}
\hline & Initial & Extraction \\
\hline Teacher' ignorance toward the digital & 1.000 & .531 \\
assessment & & \\
Teachers' awareness of using technology & 1.000 & .507 \\
Insufficient information about digital & 1.000 & .748 \\
literacy assessment & & \\
Creative thinking & 1.000 & .660 \\
Digital technology convenience & 1.000 & .384 \\
\hline
\end{tabular}

From the results above, it is known that the factor of teachers' ignorance toward digital assessment is 0.531 or $53.1 \%$, teachers; awareness 0.507 or $50.70 \%$, insufficient information is 0.748 or $74.8 \%$, creative thinking skill is 0.660 or $66.00 \%$, and the convenience of using digital literacy assessment is 0.384 or $38.40 \%$. In brief, it can be concluded that the average explanation is above $50 \%$, so the factors will still be determined and continued with further analysis. Followed by the "core" of the confirmatory factor analysis, in order to determine how many factors may be formed can be seen from the following table:

Table 5. Total Variance Explained

\begin{tabular}{|l|r|r|r|r|r|r|}
\hline \multirow{3}{*}{ Component } & \multicolumn{3}{|c|}{ Initial Eigenvalues } & \multicolumn{3}{|c|}{ Extraction Sums of Squared Loadings } \\
\cline { 2 - 7 } & \multicolumn{1}{|c|}{ Total } & \% of Variance & Cumulative \% & \multicolumn{1}{|c|}{ Total } & \% of Variance & Cumulative \% \\
\hline 1 & 2.830 & 56.599 & 56.599 & 2.830 & 56.599 & 56.599 \\
2 & .845 & 16.892 & 73.492 & & & \\
3 & .585 & 11.699 & 85.191 & & & \\
4 & .443 & 8.867 & 94.058 & & & \\
5 & .297 & 5.942 & 100.000 & & & \\
5
\end{tabular}

From the table above, it is known that the component ranges from 1 to 5 in which all independent variables are represented. By considering the Initial Eigenvalues column with SPSS determining the value 1 , the variance that can be explained by a factor 1 is 2.830 $/ 5 \times 100 \%=56.599$. Thus, it is because the Initial Eigenvalues 
are set to 1 , the total value to be taken is more than $1(>1)$, which is component 1 as shown in table 6 .

Table 6. The Result of Component 1

\begin{tabular}{|l|r|}
\hline & Component \\
\cline { 2 - 2 } & \multicolumn{1}{|c|}{1} \\
\hline Teacher' ignorance toward the digital & .728 \\
assessment & .712 \\
Teachers' awareness of using technology & .865 \\
Insufficient information about digital & .812 \\
literacy assessment & .620 \\
Creative thinking & \\
Digital technology convenience & \\
\hline
\end{tabular}

3.2 The Result of Teachers' Perception on the Assessment of Islamic-based Digital

\section{Literacy Skill}

After the survey, the team have discussion to set up the training program. Since the outbreak, the training is held in two days by inviting 15 teachers coming and participating during the training.

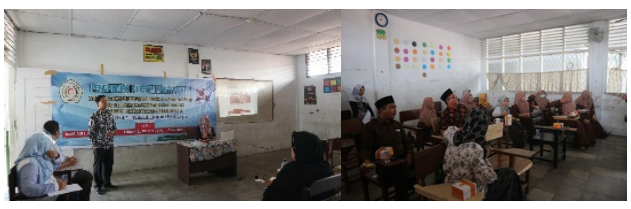

Figure 1. The day of Program

In day 1 , the teachers are given the training of the implementation of Projectbased Learning in which team explains all the stages in details, and give some ideas of project related with certain subjects taught by them. In fact, the teachers still seem to be confused to create their own project that is related with the subject taught, and the way to connect the idea of the project with Islamic values. Most teachers think of Islamic values only can be linked with the religion subject. Moreover, all the teachers have never experienced implementing Project-based Learning so that this training become a new insight for them.

Due their curiosity, they keep paying attention fully to the team in order to catch up the idea. In this case, team introduce one kind of project, namely; video project. Team said that Project-based Learning with creating creative video leads to digital literacy skill, because the students will read, speak, listen, and even write their own sentences in that video. Certainly, the teachers become more interesting since team inform them that there are many free video maker applications that are available in smartphone and familiar for the students so teacher do not need to be doubt to ask the students making video, the video maker application such as; vivavideo, instashot, kinemaster, and ect.

Specifically, the video project made needs to be assessed. The teachers have a new information that there are two kinds of assessment, namely; assessment of learning, and assessment for learning. Assessment for learning is carried out during the process of making the project, so the teacher needs to assess them by giving them some information, explanation in order to improve the project. While, assessment for learning tend to give score or number (iTELL team, komunikasi personal). Since the new normal era, teachers are suggested to use assessment of 
learning rather than assessment for learning. Thus, the teachers are expected to appreciate the students' process of making the video.

In day 2, the teachers are given the opportunities to think of a video project that is linked to Islamic values; Al Qu'ran, Hadits. One of science teacher design the video project themed the Earth. In this project, the teachers ask the students to make the video collage of the changing of Earth, and ask the students to insert QS Fussilat (41) Verses 9-12, which explains that the earth was created by Allah SWT for two periods, From this explanation, it makes it easier for the Islamic-based assessment according to the characteristics of the school.

Moreover, English teacher of the school has a brilliant idea to make the project of narrative text. She designs video project that presents best childhood memory with parents by displaying students' childhood photos, and connect it with QS Al-Isra (Verse:2324). Hence, the video needs to be assessed, but the reality the teachers have no information how to assess it comprehensively. Based on the video project, teachers are guided to Islamic-based digital literacy skill assessment.
In day 2, team explains the form assessment. Teacher are trained to carry out assessment of learning by assessing the process; how the students read, how the students analyze video references, how the students write their own sentence, and how the students create the video. In details, the form of assessment is seen in figure 2 .

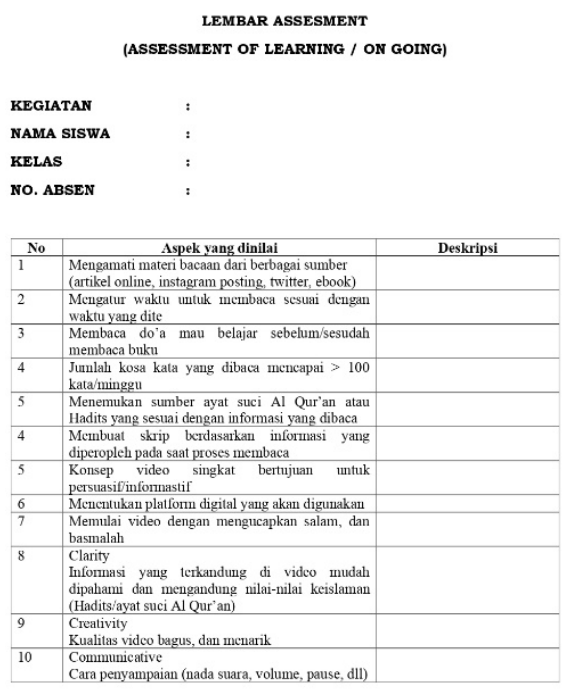

Figure 2. Assessment of Learning Sheet

From the figure above, the assessment of learning is focused on Islamic characters carried out by the students during project completion. Then, Islamic-based digital literacy skill assessment is assessed by using google form through bit.ly/MTSIKIPAW as seen in figure 3 . 


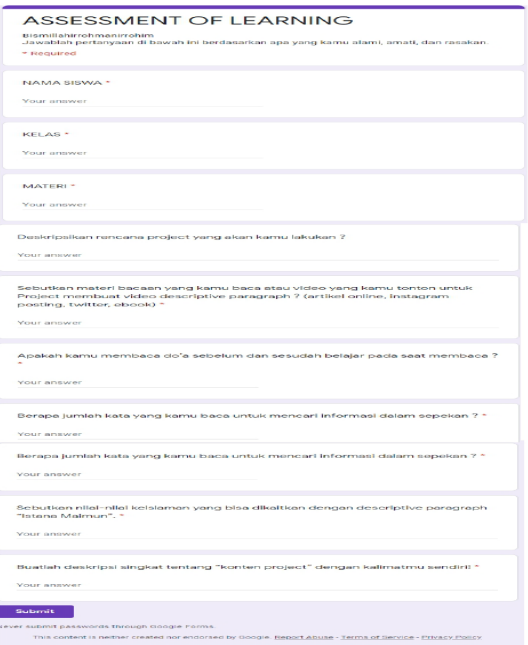

Figure 3. The Display of

Islamic-based digital

literacy skill assessment by using Google Form

Beside google form, teacher also can assess the students through voccaro. It is kind of online voice recorder that can record the voice, and send it directly to the students. Therefore, the students can hear teachers voice, and students are free to reply as well. The following figure shows the display of voccaro application.
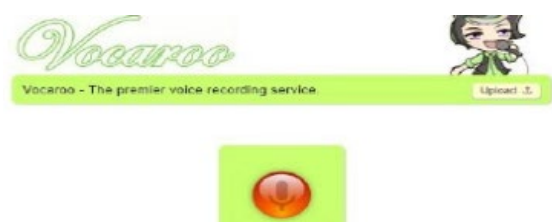

\section{Figure 4. Voccaro Application}

Based on questionnaire distributed, it is found that teachers have a good perception on implementation Project-based Learning and Islamic-base digital literacy skill as shown in table 6 .
Table 7. The Result of Teachers' Perception on PBL

\begin{tabular}{|l|r|r|r|r}
\hline & Frequency & Percent & \multicolumn{1}{c|}{$\begin{array}{c}\text { Valid } \\
\text { Percent }\end{array}$} & $\begin{array}{c}\text { Cumulative } \\
\text { Percent }\end{array}$ \\
\hline Valid Agree (A & 8 & 53.3 & 53.3 & 53.3 \\
$\begin{array}{l}\text { Strongly } \\
\text { Agree (SA) }\end{array}$ & 7 & 46.7 & 46.7 & 100.0 \\
Total & 15 & 100.0 & 100.0 & \\
\hline
\end{tabular}

From the table above, teachers who state agree are $53.3 \%$, and $46,7 \%$ of teachers says strongly agree. Moreover, teachers' perception on carrying out the assessment of students' project is presented in table 8 .

Table 8. The Result of

Teachers' Perception on

Carrying out the Assessment of Students' Project

\begin{tabular}{|l|r|r|r|r|}
\hline & Frequency & Percent & $\begin{array}{c}\text { Valid } \\
\text { Percent }\end{array}$ & $\begin{array}{c}\text { Cumulative } \\
\text { Percent }\end{array}$ \\
\hline Valid Agree & 7 & 46.7 & 46.7 & 46.7 \\
Strongly & 8 & 53.3 & 53.3 & 100.0 \\
Agree & 15 & 100.0 & 100.0 & \\
Total & \\
\hline
\end{tabular}

Then, teachers also state that this kind of assessment is extremely suitable with the current covid19 outbreak situation, in details is seen in table 9.

Table 9. The Result of Teachers' Perception on the Form Assessment Suitable with New Normal Era

\begin{tabular}{|l|r|r|r|r|}
\hline & Frequency & Percent & \multicolumn{1}{|c|}{$\begin{array}{c}\text { Valid } \\
\text { Percent }\end{array}$} & $\begin{array}{c}\text { Cumulative } \\
\text { Percent }\end{array}$ \\
\hline Valid Agree & 8 & 53.3 & 53.3 & 53.3 \\
Strongly & 7 & 46.7 & 46.7 & 100.0 \\
Agree & 15 & 100.0 & 100.0 & \\
Total & & \\
\hline
\end{tabular}

Then, the result of questionnaire also shows that most teachers agree that Islamic-based digital literacy skill that is linked to Islamic values can be applied in any 
subject. Clearly, the data is visualized in table 10 .

Table 10. The Result of Teachers' Perception on Islamic-based Assessment is Applicable to All Subjects

\begin{tabular}{|l|r|r|r|r|}
\hline & Frequency & Percent & \multicolumn{1}{c|}{$\begin{array}{c}\text { Valid } \\
\text { Percent }\end{array}$} & $\begin{array}{c}\text { Cumulative } \\
\text { Percent }\end{array}$ \\
\hline Valid Neutral (N) & 1 & 6.7 & 6.7 & 6.7 \\
Agree (S) & 6 & 40.0 & 40.0 & 46.7 \\
Strongky Agree & 8 & 53.3 & 53.3 & 100.0 \\
(SS) & & & & \\
\hline
\end{tabular}

Then, the result of the data shows that Islamic-based digital literacy skill assessment lead to character building such as; independent, creative, Islamic character.

Table 11. The Result of Teachers' Perception on Islamic-based Assessment Leads to Students' Character

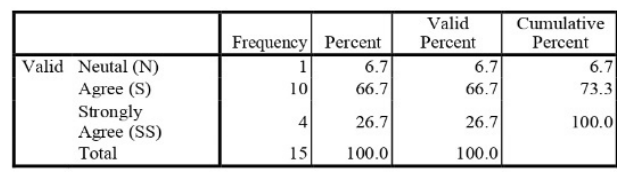

In short, 10 questions of questionnaire are displayed in figure 2 .

\section{|||||||||||| \\ Figure 5. The Result of \\ Teachers' Perception on the Program}

3.3 The Result of Students' Improvement in Carrying out Islamic-based Digital Literacy Skill through PBL
After the training program, teachers' understanding of carrying out Islamic-based Digital Literacy Skill through PBL is highly increased. Detailly, the data is shown in data below

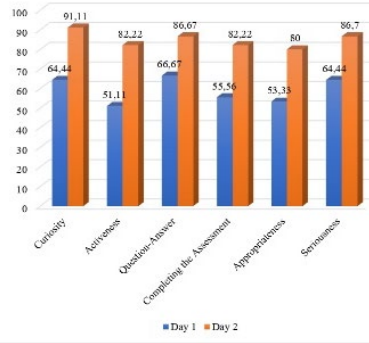

Figure 6. The Differences of Day 1 dan day 2

The data above clearly shows that there are six indicators investigates from day 1 dan day 2, namely; curiosity, activeness, questionanswer, completing the assessment, appropriateness, and seriousness, in which each indicator is higher than day 1. It means that teachers' understanding of Islamicbased digital literacy skill assessment through PBL become much better. In other words, teachers are really expected to have digital assessment knowledge in this current era in order to enhance professional life. It is similar with a study conducted by Burnett reporting that teachers' experiences in practicing digital literacy bring up to both personal and professional lives (Burnett, 2011). Moreover, the use of digital tool gives a great impact to interaction quality, social domain, and fulfilling students' need (Tanyel, Knopf, 
2011). It is similar with a study revealing that the use of digital does not only touch cognitive aspect but it also reaches the social interaction (Stenalt, 2020). Then, Project-based learning serves multi aims of learning, such; creativity, communication skill (Lubis, 2019), and through video project the students may go further to digital literacy skill journey. Therefore, it implies that teachers' ability in carrying out Islamic-based digital literacy assessment can be constantly enhanced through project-based learning implementation that is linked with Islamic values. Then, teachers fully involve in each literacy activities during students' project completion by giving the feedback that focuses on the process, Islamic values rather than scoring.

\section{CONCLUSION}

Project-based learning is deserved a position in Islamic senior high school, teachers are asked to freely design the project with Islamic values. Each value that have been experienced need to be assessed with Islamic-based digital literacy skill since students automatically read, listen, speak, write on online platform, and create a video project linking with Islamic values; $\mathrm{Al}$ Qur'an and Hadits. Some online learning application support the digital assessment in new normal era.

\section{ACKNOWLEDGMENT}

The authors would like to express sincere gratitude to The Ministry of Education and
Culture, General Directorate of Research, Technology, and Higher Education for the financial support.

\section{REFERENCES}

Burnett, C. (2011). Pre-service teachers' digital literacy practices: exploring contingency in identity and digital literacy in and out of educational contexts. Language and Education, 25(5), 433-449.

Dashtestani, R., \& Hojatpanah, S. (2020). Digital literacy of EFL students in a junior high school in Iran: voices of teachers, students and Ministry Directors. Computer Assisted Language Learning, 1-31.

Greaves, L., Bradley, C., \& Holley, D. (2012). Learning journeys: exploring approaches to learner digital literacy acquisition. Enhancing Learning in the Social Sciences, 4(2), 1-17.

Lubis, N., Lubis, A., \& Ashadi, R. I. (2018). Integrating Teaching Models to Enhance Efl Students' Interpersonal Communication Skill and Creativity. International Journal of Education and Literacy Studies, 6(4), 129-137.

Lubis, N., \& Lubis, A. (2019, April). Enhancing 21st Century Skill through Teaching Model Collaboration in Indonesian EFL Classroom. In $3 r d$ Asian Education Symposium (AES 2018). Atlantis Press.

Mulyasa, H.E. Pengembangan dan Implementasi Kurukulum 2013. PT Remaja Rosdakarya. Bandung. 2013

Stenalt, M. H. (2020). Researching student agency in digital education as if the social aspects matter: students' experience of participatory 
Amaliah: Jurnal Pengabdian Kepada Masyarakat Volume 4 No 2 November 2020 ISSN 2580-0337 (print), ISSN 2580-0531 (online)

dimensions of online peer

assessment. Assessment \&

Evaluation in Higher Education, 1-

15

Tanyel, N., \& Knopf, H. T.

(2011). Does using

digital media in

assessment affect teacher

practices in infant and

toddler

classrooms?. Internation

al Journal of Early Years

Education, 19(3-4), 297-

311. 